\title{
Invasão à Crimeia: influência ocidental na Ucrânia e retaliação Russa
}

\author{
Crimea invasion: western influence in \\ Ukraine and Russian retaliation
}

\author{
DOI: $10.21530 /$ ci.v15n1.2020.942
}

\author{
Alexandre Cesar Cunha Leite ${ }^{1}$ \\ Arthur Mastroiani Máximo de Lucena² \\ Fábio Rodrigo Ferreira Nobre ${ }^{3}$
}

\section{Resumo}

Este artigo tem o intuito de analisar as medidas de política externa adotadas pela Rússia nos anos de 2014-2015 que resultaram na invasão da Federação à Crimeia, sob a ótica do Modelo de Hermann, com a seguinte questão norteadora: diante da invasão à Crimeia e quebra da soberania do país, em que medida as ações de política externa da Rússia foram influenciadas pelas mudanças de governo na Ucrânia? Para isto, levou-se em consideração breve contexto histórico da crise ucraniana, bem como as três mudanças de governo em curto prazo e se aplicou o modelo de Hermann, contextualizado com o entendimento conceitual de Guerra Híbrida, uma vez que as estratégias de guerra do governo russo na Crimeia foram de vias convencionais e não convencionais. Como síntese da pesquisa aqui apresentada, produziu-se um quadro demonstrativo da aplicação do Modelo de Hermann nas mudanças dos governos ucranianos e os tipos de guerra observados.

Palavras-chave: Rússia; Ucrânia; Criméia; Guerra Híbrida.

1 Doutor em Ciências Sociais (linha de Relações Internacionais) pela PUCSP. Docente do Programa de Pós-Graduação em Relações Internacionais da Universidade Estadual da Paraíba (PPGRI/UEPB), docente do Programa de Pós-Graduação do Programa de Gestão Pública e Cooperação Internacional da Universidade Federal da Paraíba (PGPCI/UFPB) e docente do Programa de Pós-Graduação em Relações Internacionais da Pontifícia Universidade Católica de Minas Gerais (PPGRI/PUCMINAS). ORCID: http://orcid.org/0000-0002-0209-2717; email: alexccleite@gmail.com

2 Mestre em Relações Internacionais da Universidade Estadual da Paraíba (PPGRI/UEPB). ORCID: http://orcid.org/ 0000-0001-9361-9395; email: arthurmastroiani@gmail.com

3 Doutor em Ciência Política pela Universidade Federal de Pernambuco (PPGCP/UFPE). Docente do Programa de Pós-Graduação em Relações Internacionais da Universidade Estadual da Paraíba (PPGRI/UEPB). ORCID: http://orcid.org/0000-0002-2905-0541; email: fabio.f.nobre@gmail.com

Artigo submetido em 21/04/2019 e aprovado em 16/03/2020. 


\begin{abstract}
The paper was carried out with the purpose of analyzing the foreign policy measures adopted by Russia in 2014-2015, which resulted in the invasion of the Federation to Crimea. Our starting point is taking the perspective of the Hermann Model, with the focus question: facing the invasion of Crimea and sovereignty of the country, in which extent has Russia's foreign policy actions been influenced by changes in government in Ukraine? Considering this purpose, we start with a brief historical context of the Ukrainian crisis, the three changes of government in short term and application of the Hermann's model of Hermann, contextualized with the understanding of hybrid war, since the strategies of war of the Russian government in the Crimea were conventional and non-conventional. As synthesis of the realized research, we produce a table to demonstrate the application of the Hermann Model in the changes of the Ukrainian governments and the types of war observed.
\end{abstract}

Keywords: Russia; Ukraine; Crimea; Hybrid War.

\title{
Introdução
}

O objetivo deste artigo é analisar as medidas de política externa (PE) da Rússia direcionadas à Ucrânia, notadamente aquelas que implicaram quebra da soberania do país e resultaram em mudanças de direcionamento político russo com a invasão da Federação Russa (FR) à Crimeia. Opta-se por realizar a análise tomando o modelo de (Hermann 1990), considerando a seguinte questão norteadora: diante da invasão à Crimeia e a quebra da soberania do país, como as ações de PE russa foram influenciadas pelas mudanças de governo na Ucrânia?4

O objeto se encontra centrado nas ações do presidente Vladimir Putin direcionadas à Crimeia após as mudanças governamentais na Ucrânia. Sustenta-se que a FR utilizou a denominada Guerra Híbrida (GH) (Dayspring 2015; Fernandes 2016; Chivvis 2017; e Trenin 2018). A análise encontra-se dividida em três níveis: a) descrever e analisar o contexto histórico do conflito na Ucrânia envolvendo o mercado energético entre Ocidente e russos; b) descrever as mudanças de governo ocorridas na Ucrânia com posições antagônicas entre pró-russos e próocidentalistas e, por fim; c) analisar o posicionamento da política externa da Rússia com a invasão da Crimeia, aplicando duas características do Modelo de

4 Este artigo é parte de pesquisa em andamento realizada com financiamento do Conselho Nacional de Desenvolvimento Científico e Tecnológico (CNPq) e da Coordenação de Aperfeiçoamento de Pessoal de Nível Superior (CAPES). Os autores agradecem aos pareceristas pelas sugestões e contribuições que originaram esta versão do texto. 
Hermann que envolvem os estágios da tomada de decisão de Putin e o que se entende por GH como medida da FR.

O intuito não é a aplicação completa do modelo, mas usar duas das sete características que Hermann apresenta em seu estudo dos estágios da tomada de decisão em PE. Segundo (Hermann 1990 14), estes estágios são classificados da seguinte maneira: 1) Expectativas políticas iniciais; 2) Ator Externo/Estímulos Ambientais; 3) Reconhecimento de Informações Discrepantes; 4) Postulação de uma Conexão entre Problema e Política; 5) Desenvolvimento de Alternativas; 6) Construir Consenso Autoritário para Escolha e; 7) Implementação de Nova Política. Dentre as sete características de (Hermann 1990) propõe-se a utilização de duas: a postulação de uma conexão entre problema e política e a implementação de uma nova política.

Ainda que não sejam utilizados todos os estágios propostos pelo modelo de (Hermann 1990), para os excluídos existem associações objetivas entre as medidas de PE de Putin para a Ucrânia e os estágios não selecionados. Desta forma, cabe elucidá-los como justificativa e contextualização do problema.

Como o governo russo, em sua política externa, tem adotado medidas objetivas de causa e efeito com a Ucrânia, dada a invasão ao território da Crimeia e quebra de soberania do país, foram utilizados dois estágios. Seguem os motivos: a) postulação de uma conexão entre problema e política: intuito de analisar o efeito e a consequência do que ocorreu com as mudanças de governo ucraniano, para aceitação ou não de acordos econômicos ocidentais e b) implementação de uma nova política: diante das mudanças governamentais ucranianas, a Rússia adotou novo direcionamento político com a Ucrânia, resultando na anexação da Crimeia. Ademais, segundo o modelo, como toda implementação de nova política advém de processo decisório do tomador de decisão, as mudanças de governo ucraniano e, consequentemente, de direcionamento político contrário aos interesses políticos e econômicos russos, resultam em invasão militar e quebra da soberania ucraniana.

Não surtiriam efeitos analíticos visíveis as seguintes características, pelos seguintes motivos: a) para o estágio Expectativas Políticas Iniciais - desde o início do conflito ucraniano entre pró ocidentalistas e pró russos, Putin já havia demonstrado sua posição preliminar com relação à Ucrânia, de não aceitação de influência Ocidental nos assuntos domésticos ucranianos; b) Ator Externo/ Estímulos Ambientais - os atores envolvidos estão explícitos na análise realizada, o que descarta o uso deste; c) Reconhecimento de Informações Discrepantes este reconhecimento de quebra de informação ou de informações discrepantes 
é transparente em comparativo dos governos russo e ucraniano analisados, visto que Putin tinha acesso livre à informação do que ocorria na Ucrânia, e; d) Desenvolvimento de Alternativas - Putin, na avaliação de política externa realizada, não usou meios alternativos de ação; seus objetivos eram claros e específicos para não perder espaço de influência política e econômica no país. Todavia, mesmo existindo clara vinculação de causa e efeito, estes estágios serão citados na aplicabilidade do modelo como forma de contextualização.

Antes de adentrar na análise de PE na tomada de decisão do governo Putin, conforme o modelo proposto por (Hermann 1990), apresenta-se a explicação da situação-problema abrangendo a hipótese do envolvimento do interesse político/ econômico russo na Ucrânia, especialmente os acordos energéticos ocidentais ucranianos que conduziram a mudança da política externa russa para intervenção no país. Os estágios "a postulação de uma conexão entre problema e política" e a "implementação de uma nova política" serão utilizados para analisar a associação entre o direcionamento ucraniano em alterar seus parceiros comerciais para a vertente pró-ocidental e a atuação da mudança de política externa russa em responder a este novo direcionamento do governo ucraniano, apresentando como resultado a invasão à Crimeia.

Para isto, serão debatidas as mudanças de governo da Ucrânia envolvendo (os) três (últimos) presidentes: Víktor Yanukovytch (2010-2014); Oleksandr Turtchynov (2014-2014) e Petro Poroshenko (2014-2019). Da mesma forma, atribuise relevância à posição militar da Rússia durante os processos de debate dentro da Ucrânia entre pró-russos e pró-ocidentais, e, por fim, a invasão à Crimeia pela Federação Russa em 2014.

\section{O conflito ucraniano e o interesse da Federação Russa no país}

A Rússia, desde suas ações durante a Guerra Fria até sua formação democrática, tem na ascensão ao poder de Vladimir Putin na virada do século XXI uma ruptura pragmática em sua estrutura, modificando a ideologia política vigente no país. Estas modificações, observáveis com a presença de Vladimir Putin, não foram repentinas, quando se observa o governo de Boris Yeltsin e as tentativas de mudanças do quadro doméstico russo (Obydenkova 2011). Em meio a este momento de transformação doméstica russa gozando de certa estabilidade do governo Putin, o mundo ocidental começou a investir e influenciar países que 
antes estavam em domínio da antiga União das Repúblicas Socialistas Soviéticas (URSS) (Segrillo 2012).

Diante dos interesses econômicos de expansão da economia de mercado pela União Europeia (UE) e Estados Unidos (EUA), já se observava que países do Leste Europeu como Ucrânia, Polônia, República Tcheca, Lituânia, Letônia e Sérvia, entraram na zona de comércio e influência Ocidental, o que aumentou a preocupação dos russos no que diz respeito aos seus interesses econômicos, políticos e no que concerne à sua área de influência regional. Na prática, para a FR, este evento é visto como perda de mercado na região. Frente à necessidade de modernização da Rússia e de sua inserção na economia mundial, a perda de espaço competitivo gera incerteza e pressão para uma ação reativa na política externa (Csaba 1996).

Entende-se a preocupação do governo russo com relação à expansão Ocidental em sua antiga área de influência; dentre os países citados, a Ucrânia é aquele que, para os russos, foi e continua sendo um espaço político e econômico essencial, compondo parte de uma agenda de ação de PE russa no âmbito regional. Em sua história, a Ucrânia pertencia à zona de influência da antiga URSS como República membro. Após o fim da URSS, em 1991, a Ucrânia se tornou livre. Conforme se notou nos países do Leste Europeu (p.e. Hungria, Eslováquia e Polônia), os Estados desta região se voltaram para o eixo de influência ocidental. Muitos destes como membros da UE. Na Ucrânia, o processo não aconteceu pacificamente, visto que existem no país dois grupos (pró-ocidentalistas e pró-russos) que seccionam a sociedade ideologicamente e influenciam na mentalidade social-política (Csaba 1996).

Perante esta segmentação social entre pró-ocidentalistas e pró-russos, em 2010, no governo de Viktor Yanukovytch, ocorreu quebra de contratos com a UE, associada às relações econômicas em que prevaleceram o interesse da FR. Yanukovytch argumentava não ser vantajosa a influência econômica da UE, pois os principais favorecidos, sobretudo vinculados ao mercado energético (petróleo e gás natural), seriam os Ocidentais e não os ucranianos. Yanukovytch, mesmo com as pressões internas para rebater a aproximação com a Rússia, tendia ao lado pró-russo e, via meios legais ucranianos, levou o país para a zona de influência da Rússia (Lewis 2014).

$O$ retorno à zona de influência russa ocorreu por pressão da conjuntura ucraniana. A Rússia ameaçou cortar o abastecimento de gás natural para a Ucrânia caso o país não seguisse sua estratégia. Como a Ucrânia é dependente do produto energético, entende-se que a decisão decorre da atuação de uma política coercitiva 
que influenciou a decisão ucraniana. Os gráficos 1 e 2 indicam grau de dependência do governo ucraniano ao se observar sua balança comercial, determinada pelo fluxo de petróleo e gás natural com os russos, entre outros fatores.

Gráfico 1: Importação de produtos energéticos na Ucrânia — por país (2015)

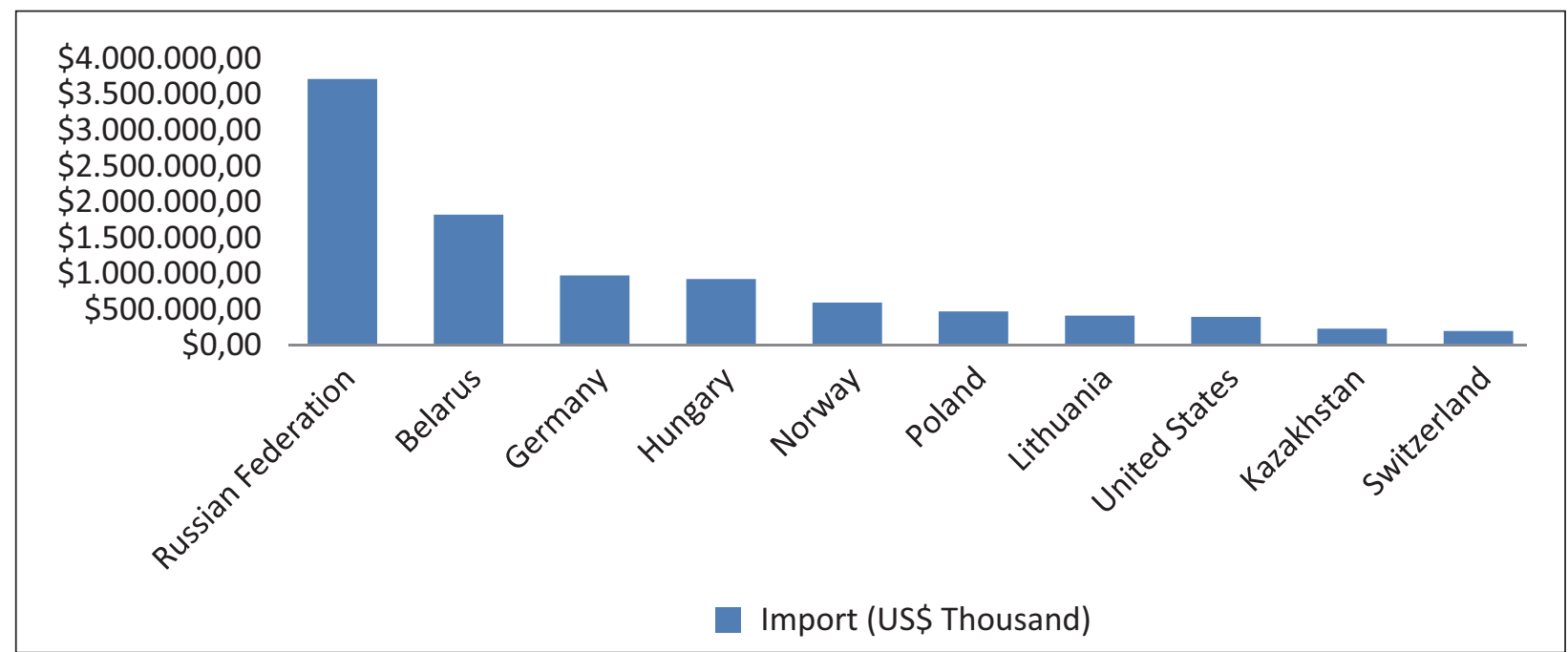

Fonte: (World Bank 2018). Elaboração própria.

Ao analisar os principais produtos importados pela Ucrânia da FR, segundo o World Bank (2015), observa-se que, além de produtos com alto valor agregado, a Ucrânia é dependente em outros setores, como alimentação, tecidos, plástico e borracha. Na prática, percebe-se que a predominância russa no mercado ucraniano tende a aumentar sua dependência.

\section{Gráfico 2: Principais produtos importados da Rússia pela Ucrânia (2015)}

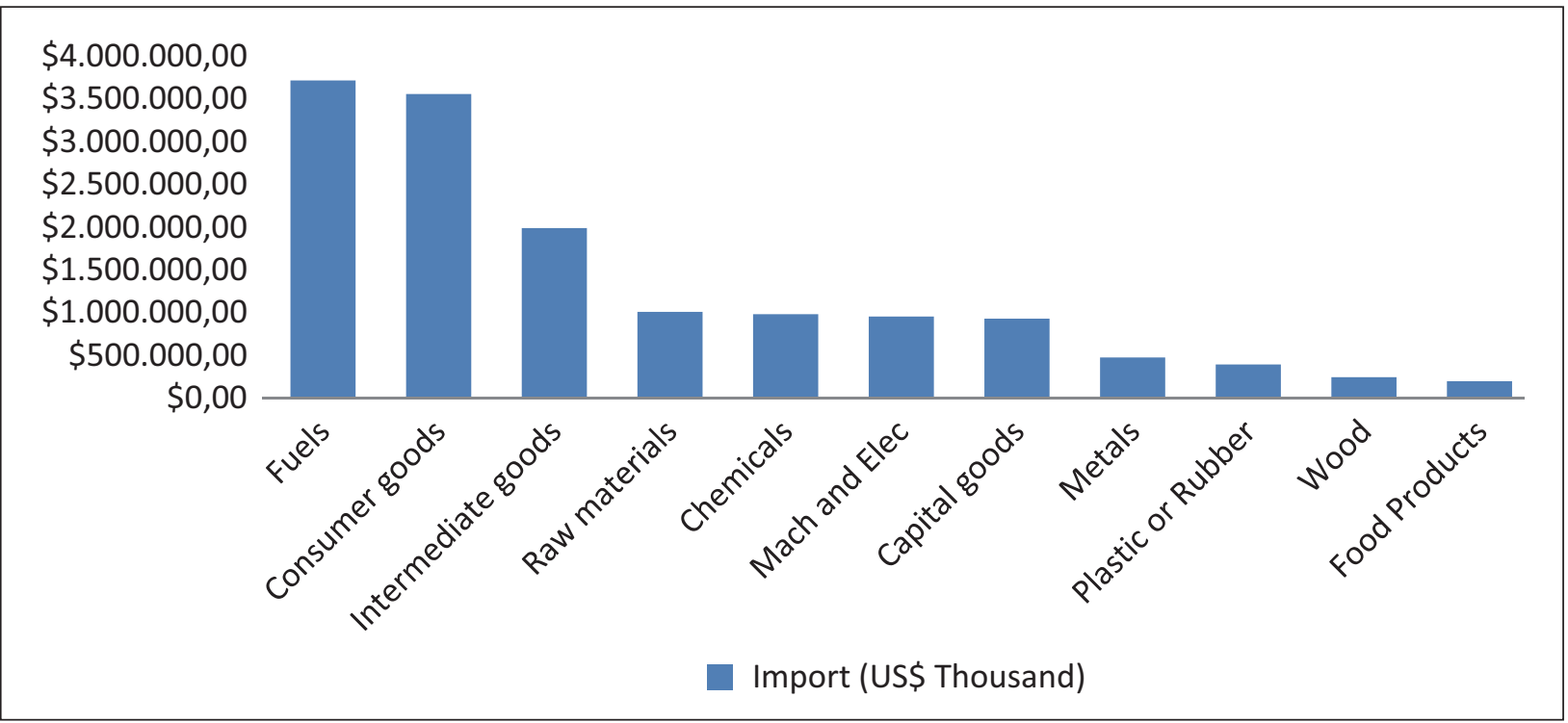

Fonte: (World Bank 2018). Elaboração própria. 
Segundo os dados expostos, entende-se que, estrategicamente, a Ucrânia é um parceiro relevante para a Rússia, particularmente, no setor energético. Logo, assume-se que perder o mercado ucraniano para a UE tenha consequências negativas na sua balança comercial, indo contra a diretriz de política comercial desenhada nas ações de PE russa. As medidas de PE por vias militares, adotadas por Putin na Crimeia, evidenciam o interesse russo na Ucrânia em assuntos considerados estratégicos.

Caso ocorresse o corte do fornecimento de gás natural, o impacto negativo na economia ucraniana poderia criar cenário doméstico conflituoso, que traria consequências para toda a população da região. Considerando que o repasse de gás à UE é realizado por dutos, a recusa de Yanukovytch em diversificar a economia ou em aceitar acordos com multinacionais de origem ocidental, inserindo maior competitividade no mercado ucraniano e não ratificar os acordos energéticos com a UE, intensificou, na Ucrânia, sentimento de indignação, fomentando um conflito civil entre pró-russos e pró-ocidentais (Lewis, 2014).

Frente a guerra civil ucraniana, por causa da insatisfação da sociedade e a necessidade de segurança do Estado ucraniano, a Federação Russa se insere no conflito com o intuito de defender os ideais ucranianos tradicionais e, mais que isso, os interesses russos no país. Putin despachou tropas para a Ucrânia a fim de defender o ideal eslavófilo, apropriando-se desta posição de parte da sociedade de forma pragmática, defendendo interesses políticos e econômicos russos. Os EUA, em movimento reativo e amparados pela UE, enviaram tropas da OTAN para o país, aumentando o risco de uma guerra internacional (Mielniczuk 2014; Bandeira 2019).

Diante das pressões da sociedade em forma de manifestação intensificandose na Ucrânia, Yanukovytch deixou o governo em 2014, assumindo o opositor Oleksander Turtchynov que, além de ser oposição, buscava promover maior relação com a UE, resguardado pelo apoio dos pró-ocidentalistas. Esta posição política gerou insatisfação. A Rússia compreendeu estas modificações do governo como agravante político e classificou a variação governamental como golpe no Estado ucraniano. Tal entendimento apoiava-se na tramitação parlamentar de um norteador pró-UE e anti-Rússia (Mulder 2019) que caminhava para aprovação pelo Parlamento da Ucrânia. Como resultado, novos confrontos aconteceram motivados por interesses dos pró-russos (Mielniczuk 2014; Mulder 2019).

Enquanto isso, na península da Criméia, região sul da Ucrânia, ocorreu uma movimentação social antiocidentalista. A região, composta majoritariamente 
por pró- russos e russos (em torno de $90 \%$ da população desta região), sofreu intervenção russa que resultou na anexação da Criméia ao território russo. A anexação não foi reconhecida pelo eixo Ocidental, mas positivamente avaliada por Putin, que procedeu à assinatura formal de contrato de anexão da Crimeia. Além da Criméia, a parte leste da Ucrânia, que também tem maioria pró-russa, assentiu ao movimento separatista ucraniano, elevando a legitimidade de Putin nesta investida (Mielniczuk 2014).

Em sua história, esta aproximação da população da Crimeia, assim como do leste ucraniano, ocorre por questões sociais, culturais e do próprio vínculo político secular que une os dois países. Apenas em 1950 os russos cederam o território para a Ucrânia no contexto da Guerra Fria. Porém, a Crimeia pertencia ao território russo desde o tempo do Império e era geopoliticamente estratégico aos russos, dado o acesso direto para o mar negro (Mulder 2019; Segrillo 2012).

Os Estados Ocidentais declararam infração ao direito internacional e impuseram sanções contra a FR, com o objetivo de forçar Putin a afastar suas tropas militares da região, o que não ocorreu. Tanto Vladimir Putin como seu staff governamental tinham ciência da situação de dependência tanto da Ucrânia quanto da UE dos seus recursos energéticos (petróleo, gás natural e seus derivados), acreditando que as sanções ao país não iriam perdurar (Dias 2015).

Para a Rússia, a intervenção na Criméia foi legítima pois, além das justificativas acima, houve o apoio da população sobre a anexação. Desta forma, justificouse que a Criméia e a Rússia tivessem alicerce histórico e cultural semelhante e unido, justificando a anexação da Criméia como parte do território da Rússia (Mielniczuk 2014).

(Freire 2015) apresenta pontos explicativos no que concerne à ação da Rússia na anexação da Crimeia: a) diplomacia utilizada de forma manipulada; b) intervenção militar, sanções e embargos associados aos interesses russos; c) utilização de política expansiva defensiva; d) procura de reconhecimento externo como grande potência (porém, em formato diferente do que ocorreu com a URSS, pois a Rússia compreende que o Sistema Internacional não é mais bipolar, mas multipolar); e) poder global visto de forma dispersa no século XXI e mais tendenciosa ao eixo Ásia-Pacífico (defesa do neoeurasianismo); e, f) utilização do soft power russo para sustentação da opinião pública a seu favor.

Disto isto, entre julho de 2014 até o início de 2015, o novo presidente da Ucrânia foi Petro Poroshenko, que tomou o poder após o curto momento de Turtchynov na liderança da Ucrânia. Em comparativo com seu antecessor, Poroshenko apresentou- 
se mais centrado no trato com ambas as partes (pró-russos e pró-ocidentalistas), apesar de defender um posicionamento contrário aos rebeldes que inflamaram o conflito no país (Dias 2015). Autores como (Silva 2018; Haran e Burkovsky 2014, Ferreira 2014, Kossovsky e Carley 2019) afirmam que Poroshenko é pró ocidentalista, mas a depender da pauta em debate, apresenta-se como pró-russo. Contudo, não se observou desligamento das relações ucranianas no governo de Poroshenko com Putin, visto que, além da dependência comercial que o país possui, há grande aderência dos rebeldes pró-russos à FR, o que acirrou a crise civil (Silva 2018; Haran e Burkovsky 2014; Ferreira 2014; Kossovsky e Carley 2019).

No que concerne ao nacionalismo e à identidade nacional ucraniana, Poroshenko afirmou ser nacionalista não reacionário (sendo contra os pró-russos neste sentido) e que a língua oficial do país é o ucraniano. Porém, em seus discursos, proferidos em ucraniano e em russo, Poroshenko defende o desenvolvimento das empresas nacionais, indo contra a lógica capitalista liberal proposta pela UE (Silva 2018; Haran e Burkovsky 2014; Ferreira 2014; Kossovsky e Carley 2019). Entende-se que Poroshenko é um governante pragmático. Ferreira (2014 29) aponta que Petro Poroshenko tem apenas um lado certo e imutável a defender, o seu.

No que concerne ao conflito na Ucrânia, podem-se averiguar saldos negativos quando são considerados os dados de refugiados, feridos, mortandades e fragilidade econômica em crescimento, assim como os problemas em questões energéticas. De acordo com relatórios da (ONU 2014), os saldos negativos do conflito ultrapassaram a casa dos milhares. De acordo com o relatório da (ONU 2014), verificou-se que são mais de 2.600 pessoas mortas em conflito, tanto civis como soldados. Passados dois meses, o número de mortos aumentou para 4.317 pessoas, ao mesmo tempo em que o total de feridos alcançou 9.921 pessoas (ONU 2014).

Sobre os migrantes forçados, 466.829 pessoas estão desabrigadas na Ucrânia, e outras 454.339 pessoas se encontram refugiada no exterior. Destes, 387.355 residentes na Rússia (Gráfico 3). Nestes dados constam os resultados sociais do conflito ucraniano que podem ser vinculados a dois estágios do modelo de Hermann explorados neste artigo: a postulação de uma conexão entre problema e política e a implementação de nova política. 


\section{Gráfico 3 - Conflito Ucraniano em 2014}

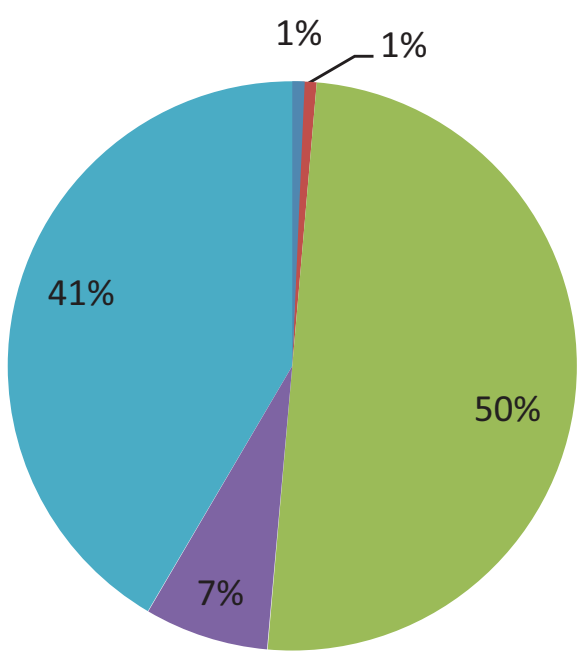

Mortos

Feridos

Desabrigados na Ucrânia

Refugiados no Exterior (diversos)

Refugiados na Rússia

Fonte: (ONU 2014). Elaboração própria.

No âmbito econômico, comparando os anos de 2010 a 2015, dentre os parceiros comerciais da Ucrânia, sobressaem-se a UE e Rússia. A FR durante muitos anos foi o principal parceiro comercial ucraniano, com destaque nas importações dos produtos energéticos. Todavia, devido às sanções da UE/Ocidente e influência na Ucrânia, especialmente a partir de 2013, a UE foi tomando lugar como o principal parceiro comercial da Ucrânia em outros setores. Somado ao conflito civil que aconteceu no país, envolvendo pró-russos e pró-ocidentais, bem como as sanções aplicadas à Rússia desde então, verificou-se queda gradativa da participação da Rússia nos proventos comercias no eixo Moscou-Kiev (Barata 2014; Mielniczuk 2014).

Expressando em números, a UE somou um terço das relações comerciais ucranianas entre 2010 a 2012 e ultrapassou os russos entre 2013-2015, tornando-se o principal parceiro em termos comerciais. Este fluxo comercial positivo envolvendo Ucrânia e UE deu-se graças a isenções tarifárias estipuladas entre os dois atores. A Rússia, devido ao conflito civil e sanções comerciais aplicadas pelo Ocidente, perdeu espaço nas trocas comerciais com o passar dos anos, como se observa nos gráficos 4 e 5, respectivamente (Barata 2014; WTO 2018). 
Gráfico 4 - Ucrânia: Comércio de Produtos Exportados

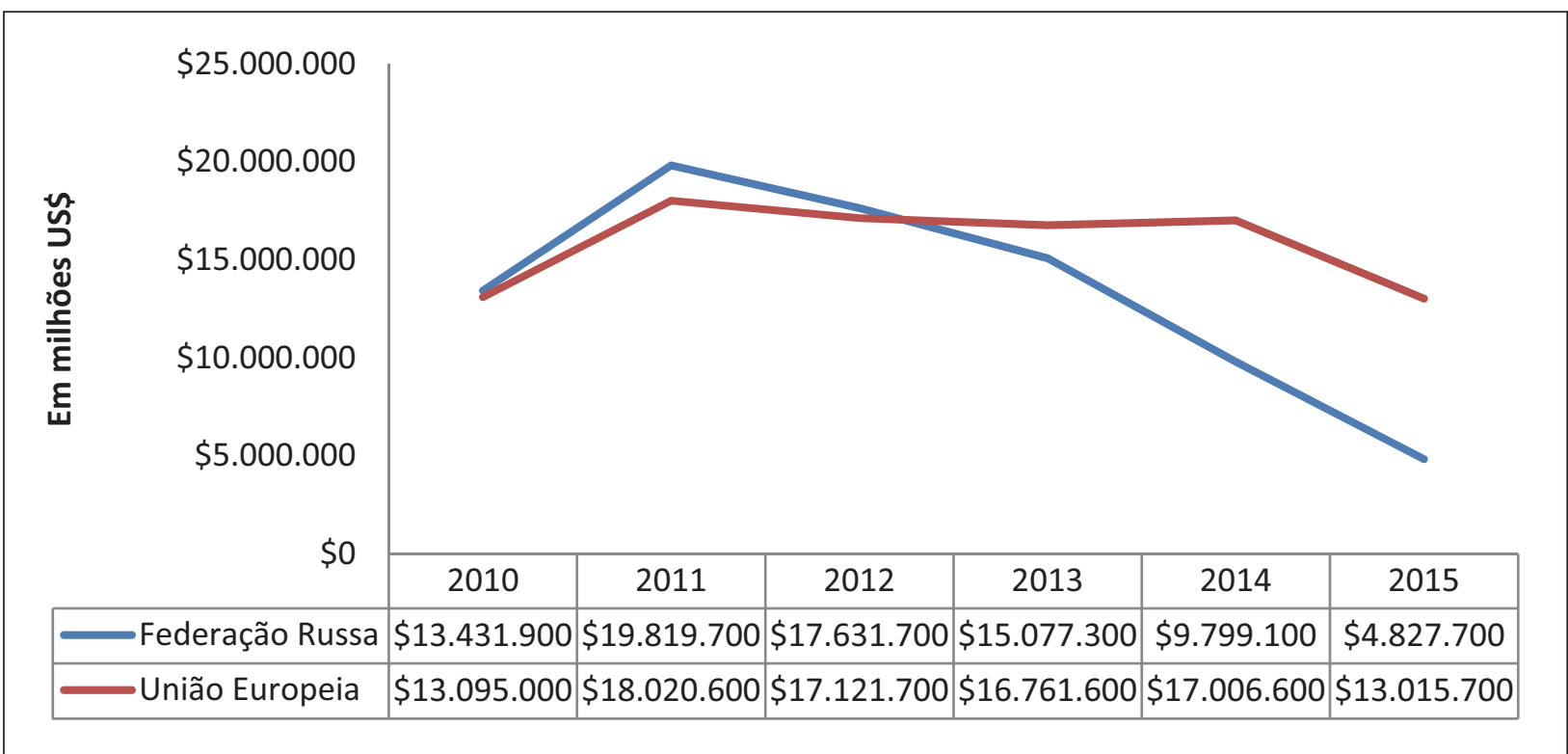

Fonte: (WTO 2018). Elaboração própria.

\section{Gráfico 5 - Ucrânia: Comércio de Produtos Importados}

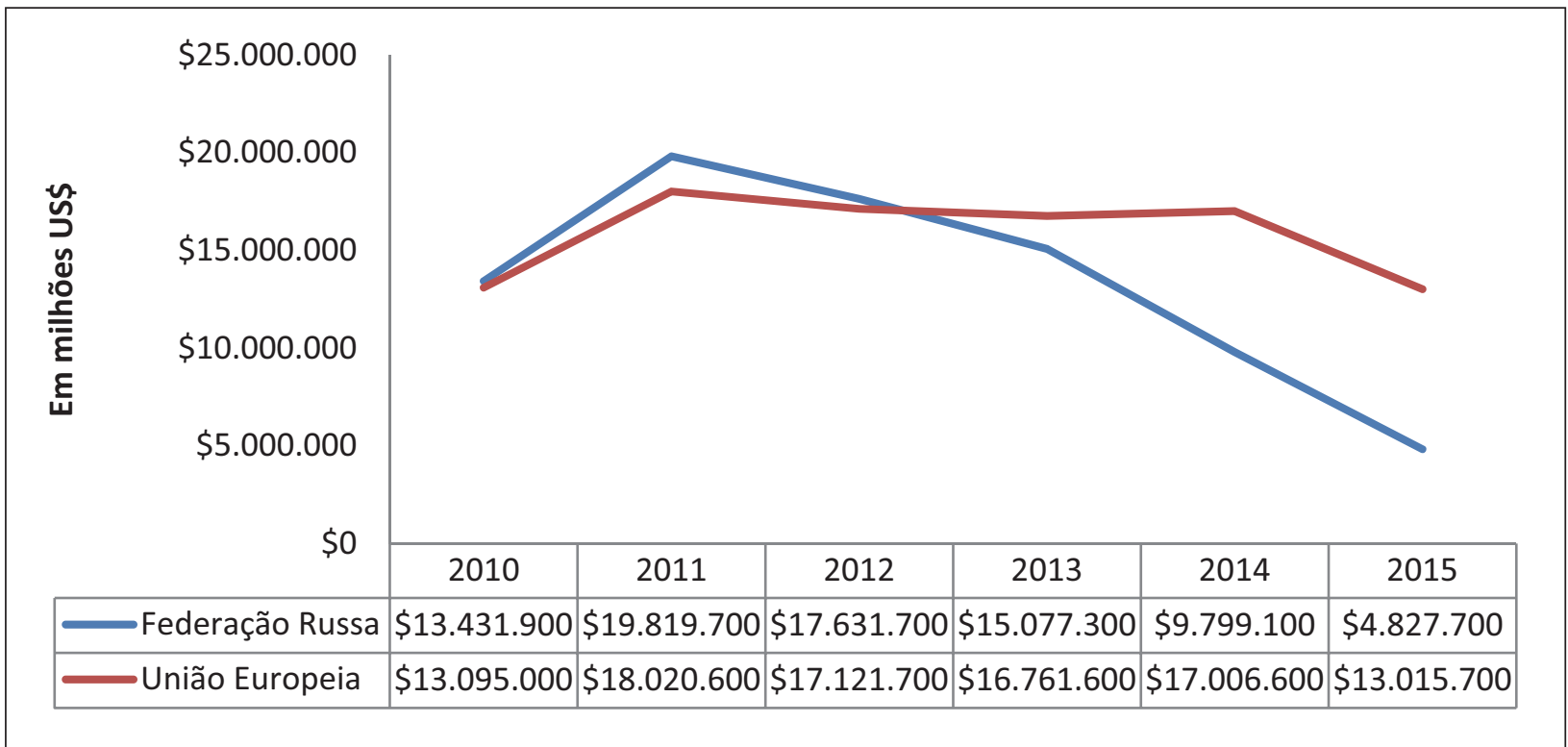

Fonte: (WTO 2018). Elaboração própria.

Países do Leste Europeu tais como Polônia, República Tcheca, Lituânia e Letônia, declararam apoio aos pró-ocidentais ucranianos. Todavia, Putin não se encontrava isolado com relação ao seu posicionamento na Ucrânia/Crimeia. Bielorrússia, Cazaquistão, Cuba, Venezuela, Nicarágua, Bolívia, Síria, Zimbábue, Armênia, Coreia do Norte e Sudão apresentaram apoio à causa russa em diversos momentos, como na própria guerra da Crimeia, em que houve um debate envolvendo estes países na ONU. No caso da Ucrânia não foi diferente (Tronenko 2016). 
Quanto à dependência da Ucrânia pelos produtos advindos da Rússia, com dados publicados pelo (World Bank 2015), observa-se expressiva dependência da Ucrânia em produtos energéticos oriundos da Rússia

Associado ao modelo de Hermann, pelos estágios postulação de uma conexão entre problema e política e a implementação de nova política, a queda dos fluxos de comércio da Ucrânia com o ocidente e, consequentemente, a perda de influência e de mercado para os russos está atrelada à relação de causa e efeito que influenciou diretamente a adoção de uma política militar intervencionista na Crimeia visando conter a expansão comercial do Ocidente no país.

\section{Aplicando o Modelo de Hermann}

Após a descrição do novo posicionamento da PE da Rússia sob o governo de Vladimir Putin e, mais especificamente, a contextualização do conflito ucraniano, assume-se o modelo de (Hermann 1990) para análise dos estágios da tomada de decisão de PE que acarretaram a anexação da Crimeia. Como informado na introdução, enfatizam-se duas características principais dentro da proposta de (Hermann 1990): postulação de uma conexão entre problema e política e a implementação de uma nova política.

Segundo este modelo, para que se compreendam as modificações no contexto de política externa de um Estado é necessário verificar as alterações em quatro características principais, com relação aos líderes, burocratas, reestruturação doméstica e choques externos. (Hermann 1990) explica as quatro características, que podem estar vinculadas ou não.

Na primeira característica, a alteração na política externa motivada pelos líderes, argumenta que as mudanças feitas derivam do líder político, sendo este o agente da tomada de decisão final (Hermann 1990).

A segunda característica enfatiza a alteração direcionada pela burocracia. (Hermann 1990) concorda que, geralmente, ao se observar este vetor de mudança não é a burocracia unificada de um Estado que adere às alterações da política externa. Até porque, em sua gênese, as burocracias são resistentes às modificações. Porém, pequena parcela desta pode trazer à tona a demanda de um novo norteador político e, para isto, persegue parcerias e ajuda para pressionar o governo.

A terceira característica, a reestruturação doméstica, (Hermann 1990) argumenta que um segmento importante da sociedade, normalmente segmentos 
da sociedade com alta influência nas camadas sociais, como as elites, por causa do conhecimento da necessidade de governabilidade da nação, pressionam por alterações na política externa com o intuito de conseguir interesses particulares.

A última característica, os choques externos, encerram um novo norteamento de política externa de um país. Como essas variações externas exercem modificações no cenário, no âmbito externo e na ordem estabelecida, elas podem afetar diretamente o país, pela movimentação da sociedade, da agenda do governo e do poder de decisão de um ou mais Estados, alterando consequentemente a estrutura e como a política externa será aplicada (Hermann 1990).

As mudanças de governo ocorridas na Ucrânia desde o início da Crise em 2014 deriva em alterações significativas no que concerne ao posicionamento da PE da Rússia com relação ao país, tendo seu ápice na anexação da Crimeia ao seu território. Na visão do direito internacional, formalmente houve uma infração à soberania estatal ucraniana e, mesmo a pressão ocidental para barrar esta PE russa na Crimeia não foi suficiente para que Putin mudasse seu posicionamento. Este evento acarretou mudança na tomada de decisão de Putin quanto à Ucrânia (Mielniczuk 2014). Segundo (Hermann 1990), para que uma alteração importante aconteça na política externa de um Estado é necessário que exista uma reformulação dos posicionamentos entre os tomadores de decisão.

No caso da Rússia, estas características são maleáveis, uma vez que o executivo é quem comanda todos os segmentos burocráticos do Estado. É onde se observa a ação doméstica pragmática de Putin, que comanda as diretrizes de política externa do país. Existindo a necessidade de mudança desta política, mesmo que de maneira radicalizada, ele pode realizá-la sem que a burocracia doméstica russa o impeça. Esta característica, que (Segrillo 2012) ressalta como Estado forte e centralizador, permite que a FR, via Putin, manuseie livremente suas decisões sem intervenções domésticas. Todavia, é importante destacar que este controle doméstico, ainda que alto, advém do pragmatismo do governo Putin em conter as resistências internas frente às mudanças políticas, visto que na Rússia formalmente existe um sistema democrático eleitoral e Putin precisa de apoio dos que detêm poder no país para continuar governando. Simultaneamente, os países Ocidentais classificam a Rússia como um dos países menos democráticos, de acordo com os dados da Freedom House (Hermann 1990; Segrillo 2012).

Historicamente, o processo político russo passou pelo absolutismo, pela monarquia constitucional, em 1917 pela democracia experimental, pelo autoritarismo 
(quando vigia a URSS) e atualmente tenta inserir a democracia de fato (governos de Yeltsin e Putin, anos 1990 e início do século XXI). A democracia na Rússia sofreu muita resistência da sociedade, já que a gosudartstvennost (Estado forte e centralizador) era mais aceita pela maioria da população russa, segundo (Segrillo 2012).

Tabela 1 - Classificação da Federação Russa como democracia segundo a Freedom House

\begin{tabular}{lccccccccc}
\hline Ano & 1985 & 1986 & 1987 & 1988 & 1989 & 1990 & 1991 & 1992 & 1993 \\
\hline Classificação & $7 ; 7 ; \mathrm{NL}$ & $7 ; 7 ; \mathrm{NL}$ & $7 ; 6 ; \mathrm{NL}$ & $6 ; 5 ; \mathrm{NL}$ & $6 ; 5 ; \mathrm{NL}$ & $5 ; 4 ; \mathrm{PL}$ & $3 ; 3 ; \mathrm{PL}$ & $3 ; 4 ; \mathrm{PL}$ & $3 ; 4 ; \mathrm{Pl}$ \\
\hline Ano & $\mathbf{1 9 9 4}$ & $\mathbf{1 9 9 5}$ & $\mathbf{1 9 9 6}$ & $\mathbf{1 9 9 7}$ & $\mathbf{1 9 9 8}$ & $\mathbf{1 9 9 9}$ & $\mathbf{2 0 0 0}$ & $\mathbf{2 0 0 1}$ & $\mathbf{2 0 0 2}$ \\
\hline Classificação & $3 ; 4 ; \mathrm{PL}$ & $3 ; 4 ; \mathrm{PL}$ & $3 ; 4 ; \mathrm{PL}$ & $3 ; 4 ; \mathrm{PL}$ & $4 ; 4 ; \mathrm{PL}$ & $4 ; 5 ; \mathrm{PL}$ & $5 ; 5 ; \mathrm{PL}$ & $5 ; 5 ; \mathrm{PL}$ & $5 ; 5 ; \mathrm{PL}$ \\
\hline Ano & $\mathbf{2 0 0 1}$ & $\mathbf{2 0 0 4}$ & $\mathbf{2 0 0 5}$ & $\mathbf{2 0 0 6}$ & $\mathbf{2 0 0 7}$ & $\mathbf{2 0 0 8}$ & $\mathbf{2 0 0 9}$ & $\mathbf{2 0 1 0}$ & \\
\hline Classificação & $5 ; 5 ; \mathrm{PL}$ & $6 ; 5 ; \mathrm{NL}$ & $6 ; 5 ; \mathrm{NL}$ & $6 ; 5 ; \mathrm{NL}$ & $6 ; 5 ; \mathrm{NL}$ & $6 ; 5 ; \mathrm{NL}$ & $6 ; 5 ; \mathrm{NL}$ & $6 ; 5 ; \mathrm{NL}$ & \\
\hline
\end{tabular}

Legenda: Mensuração de 1 a 7 com grau de liberdade política, 1 com o melhor escore e 7 o pior. "L", "PL" e "NL" são, respectivamente, “Livres”, "Parcialmente Livres” e Não Livres”.

Fonte: (Segrillo 2012). Elaboração própria.

A Freedom House classifica de 1 a 7 (quanto mais próximo de 1 seria um quadro positivo, mais próximo de 7 o oposto) o grau de liberdade política, de acordo com os direitos políticos e a liberdade da sociedade proporcionados pelo governo. A partir deste resultado, a Freedom House mensura o nível de liberdade considerando três grupos: a) Livres (L), com média entre 1,0 e 2,5; b) Parcialmente Livres (PL), com média entre 3,0 e 5,5; e c) Não Livres (NL), com médias 5,5 a 7,0. Entre os anos de 1985 e 1990, segundo a Freedom House, a Rússia teve um grau elevado de restrição de liberdade por conta do Regime adotado durante a URSS, enquanto que no início dos anos 1990 em diante, o indicador variou devido ao regime democrático instaurado no país (Segrillo 2012). Esses dados são mostrados na tabela 1 .

Em comparativo com a Freedom House, o banco de dados da ONG Levada Center traz informações relevantes a serem consideradas: a) o nível de satisfação da sociedade com as medidas que Putin toma em suas políticas; b) a satisfação do governo; e c) a aprovação da atitude do governo ante a UE (gráficos 6, 7 e 8). 
Gráfico 6: Classificação de aprovação de Putin no poder

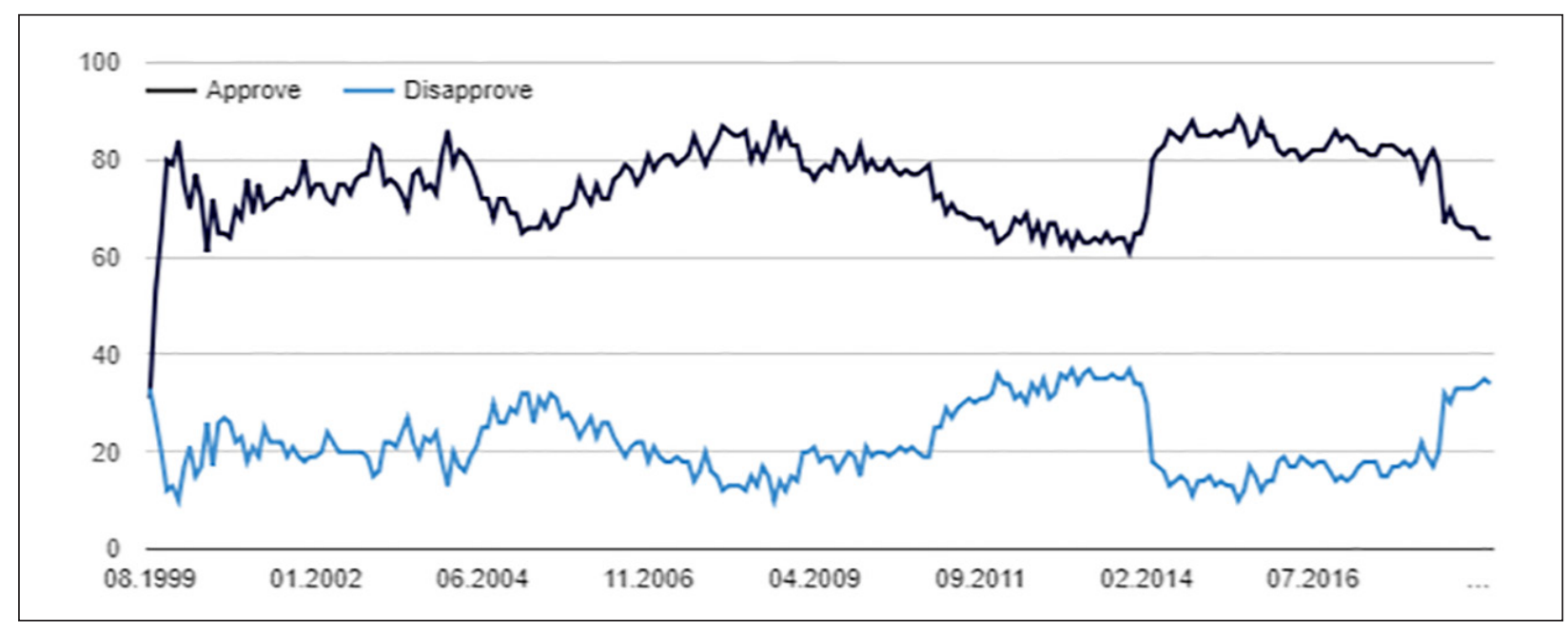

Fonte: Levada Center, tradução livre (2019).

Gráfico 7: Aprovação do Governo

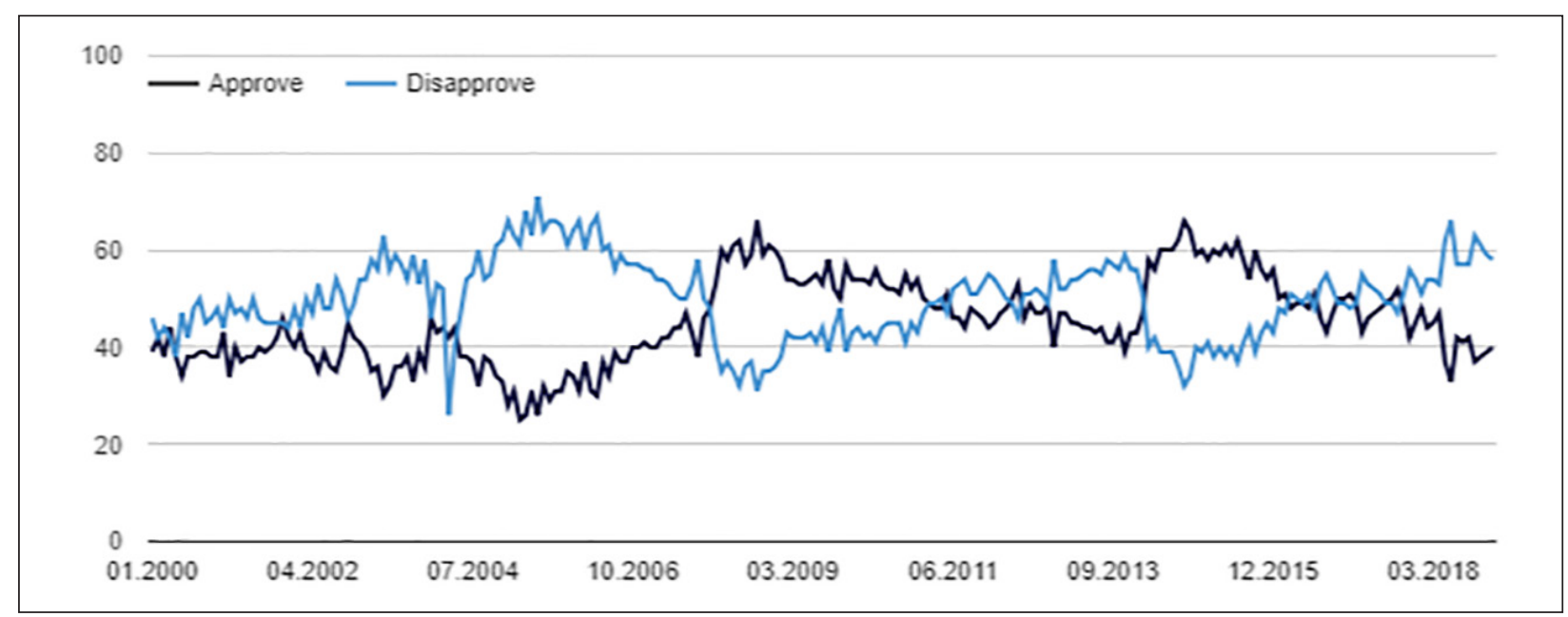

Fonte: Levada Center, tradução livre (2019)

Gráfico 8: Aprovação da atitude do governo ante União Europeia

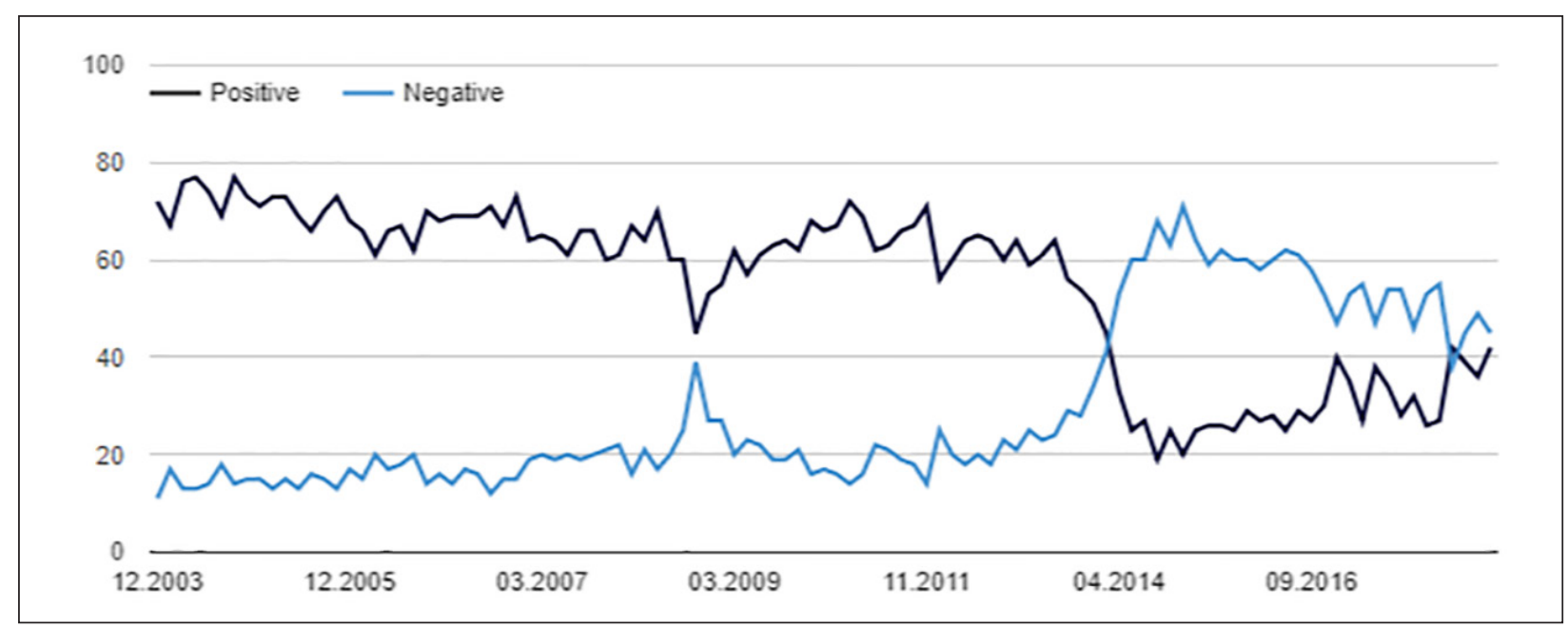

Fonte: Levada Center, tradução livre (2019) 
Os três gráficos da página anteior, tomados em conjunto, apresentam visões diferenciadas de aprovação, dependendo do tema abordado. No gráfico de “Classificação de aprovação de Putin no poder”, percebe-se o quanto o governante possui legitimidade no governo com aceitação popular alta, mesmo com o passar dos anos. No período pós 2013/2014, mesmo com a crise ucraniana, há positiva aceitação de Putin no poder, que ele se eleva quando comparada ao período 2010-2012.

No gráfico 7, “Aprovação do Governo”, percebe-se uma queda de aceitação sobre as medidas de governo adotadas. Mesmo que exista alta aderência da sociedade russa com relação à figura de Putin, as ações adotadas pelo governo, como militarização de fronteiras ucranianas e até a anexação da Crimeia posteriormente dividiu a sociedade neste quesito. No gráfico XX, "Aprovação da atitude do governo ante a União Europeia”, observa-se desaprovação após 2013. Entende-se que as sanções internacionais, ao impactar a economia, afetando a inflação, aumentaram o descontentamento quanto ao governo.

Os gráficos 6, 7 e 8, associados ao modelo de (Hermann 1990) considerando aos estágios postulação de uma conexão entre problema e política e a implementação de uma nova política, apresentam o vínculo de aceitação ou não do posicionamento político russo perante à Ucrânia, alterando quando a variável observada seja Putin como atuação executiva. Observa-se que há reprovação da atuação do governo na UE, simultaneamente a opinião social, contudo, Putin tem apoio popular como líder político no que concerne a política externa e a ação na Crimeia.

Segundo (Hermann 1990), o processo de tomada de decisão para mudança da política externa não tem caráter linear. Em situações que envolvem grandes questões, a tomada de decisão de um país está atrelada a ciclos e rompimentos e não em um ordenamento sistematizado em que um estágio acontece somente após a finalização do anterior. Os resultados não serão obtidos de forma regular. Diante disto, o autor ressalta sete características principais que compõem os estágios da tomada de decisão: 1) expectativas políticas iniciais; 2) ator externo/estímulos ambientais; 3 ) reconhecimento de informações discrepantes; 4) postulação de uma conexão entre problema e política; 5) desenvolvimento de alternativas; 6) construir consenso autoritário para escolha; 7) implementação de Nova Política.

Para o estágio expectativas políticas iniciais, o autor enfatiza que estas expectativas sobre as quais as decisões políticas são constituídas formam padrões que podem ser analisados pelo seu sucesso ou fracasso. Aplicado ao caso russo, as expectativas russas não se alteraram ao longo do processo de mudança de governantes ucranianos, assim como ao aumento de contratos comerciais ocidentais 
no país, apenas intensificaram a prática da política externa militarizada ao longo das negociações ucranianas (Hermann 1990).

O estágio ator externo/estímulos ambientais é caracterizado como a identificação dos fatores externos e como isto afetará suas políticas. Aplicado ao caso, os estímulos externos de causa e efeito da ação militar russa estão diretamente associados com a aproximação ocidental ao mercado ucraniano (Hermann 1990).

No estágio reconhecimento de informações discrepantes, (Hermann 1990) argumenta que os estímulos externos e acesso a informação podem provocar um feedback dos tomadores de decisão e quando esses estímulos estão associados às incertezas estes não podem ser ignorados ao considerar a decisão em política externa. Aplicado ao caso russo, Putin tinha acesso livre a informações sobre medidas governamentais ucranianas, visto que dentro do governo da Ucrânia existia pró-russos contrários às negociações com o ocidente. O quarto estágio, postulação de uma conexão entre problema e política, (Hermann 1990) argumenta que se há uma alteração na política, é importante identificar se há uma causa/conexão entre o problema e a política adotada. Este estágio específico será detalhado mais adiante, visto que é um dos focos da problematização do artigo.

Quanto a possibilidade de desenvolvimento de alternativas, os tomadores de decisão realizam pesquisas com o intuito de buscar alternativas diante do problema enfrentado na sua PE. No caso russo, não existiram alternativas de adoção de PE para a aproximação ucraniana ao ocidente, a tomada de decisão foi objetiva e com fins específicos. (Hermann 1990) sustenta que construir consenso autoritário para escolha envolve mais de um tomador de decisão e que, independentemente do número de atores envolvidos, a mudança na PE não pode ocorrer enquanto não for definido o consenso. No caso da FR, argumentar sobre consenso democrático é complexo e de difícil visualização, de acordo com a democracia consensual defendida por (Lijphart 2003). Segundo (Lijphart 2003), o modelo consensual se caracteriza pela abrangência de negociação e a concessão de mudanças, maior representação de mulheres no poder Legislativo, maior igualdade entre os cidadãos, satisfação perceptível com a democracia e menor distância entre a posição ideológica do eleitor e o governo. Estas não se aplicam ao caso russo. Por fim, a implementação de uma nova política implica alterar a implementação da PE de fato, após perpassar todos os outros 6 estágios (Hermann 1990).

No caso deste artigo, a mudança na PE russa envolvendo a Ucrânia, especificamente na anexação da Crimeia ao Estado Russo, aplicam-se dois dos sete estágios acima descritos: a "postulação de uma conexão entre o problema 
e a política" e a "implementação de nova política". O esforço inicial envolvendo os outros estágios não sofre alteração observável, sendo algumas delas de baixa aderência entre as variáveis e o caso em análise.

Para o estágio de "postulação de uma conexão entre o problema e a política", com a mudança de governo na Ucrânia, de Yanukovytch, que era pró-russo para Turtchynov, que era pró-ocidentalista, fez com que Putin interpretasse a mudança como um golpe de Estado, com fins específicos claros em prol de maior abertura comercial com a UE. Dada a estratégia russa, perder espaço no mercado energético para a UE na Ucrânia (em sua rota de gás natural e petróleo) fez com que a FR tomasse providências radicais contra o governo Turtchynov. Segundo (Hermann 1990) esta situação pode ser contextualizada como estágio de "implementação de nova política”.

Com o início do conflito em 2014, a Rússia armou suas fronteiras com a Ucrânia e influenciou o conflito civil em favor da parte da sociedade pró-russa, mas até então usava apenas seu softpower para isto. Com o governo de Turtchynov, Putin alterou sua PE rapidamente, analisou a região da Ucrânia que tinha maior aderência ao movimento pró-russo e, consequentemente, teria maior legitimidade, usou da cultura homogênea existente entre ucranianos e russos e, somou seu poderio militar para, finalmente, intervir e anexar a Crimeia ao seu território (Fernandes 2016).

Estes atos de intervenção na Crimeia podem ser classificados como Guerra Híbrida que, segundo (Fernandes 2016), seria a junção de atos convencionais de guerra (conflitos entre Estados), juntamente com atos não convencionais/ irregulares como, por exemplo, usar a cultura próxima entre russos e ucranianos pró-russos a seu favor. (Fernandes 2016) argumenta que a intervenção russa na Ucrânia empregou todos os mecanismos operacionais disponíveis visando seus objetivos.

O Centro Europeu de Excelência em Combate a Ameaças Híbridas (Hybrid CoE) caracteriza a ameaça híbrida em três pontos principais: (1) ação coordenada e sincronizada que visa deliberadamente as vulnerabilidades sistêmicas dos Estados e instituições democráticas usando diferentes meios; (2) as atividades exploram os limites de detecção e atribuição e as diferentes interfaces (paz/guerra, interno/ externo, local/estado, nacional/internacional, amigo/inimigo); (3) o objetivo da atividade é influenciar diferentes formas de tomada de decisão para favorecer e/ou alcançar os alvos estratégicos do agente e, simultaneamente, prejudicar o alvo (The European Center of Excellence for Countering Hybrid Threats 2019 1). 
Embora ainda não se apresente como consenso no campo da segurança internacional, o conceito de GH desponta como instrumento analítico adequado para analisar a atuação russa no caso em questão. Guerra Híbrida dá-se, em especial, pela variedade de mecanismos utilizados pelos russos, contemplando tanto aspectos convencionais como os denominados irregulares do conflito. Nesse sentido, parece acertada a definição de (Fridman 2017 42) para a GH como uma estratégia desenvolvida na zona cinzenta existente entre os conceitos de guerra regular e irregular no contexto das operações militares do século XXI.

(Fernandes 2016 30) insere o argumento que a Rússia usou três capacidades diversas (tático, operacional e estratégico) que, combinadas, contribuíram para o sucesso da medida de PE: (i) no nível tático, a Rússia empregou forças regulares, irregulares, de operações especiais e táticas com armamento convencional moderno, apoiando de forma dissimulada grupos paramilitares pró-russos, levando-os a executar operações de guerrilha numa campanha não convencional, fazendo uso dos meios cibernéticos, para afetar a Ucrânia; (ii) no nível operacional, coordenou estas ações com campanhas de guerra de informação e psicológica, usando simultaneamente formações militares convencionais; (iii) no nível estratégico, a Rússia utilizou de forma coordenada e sincronizada seus instrumentos de poder militar, diplomático, econômico e informacional de modo a alcançar os seus objetivos.

Entende-se que este posicionamento da PE russa é uma resposta do país para garantir interesses específicos de um movimento contra Ocidental, como enfraquecer a OTAN, rebelar governos pró Ocidentais contrários aos objetivos russos, anexar territórios, assegurar o acesso aos mercados europeus de seus parceiros comerciais (como exemplo da própria Ucrânia e dos Balcãs), principalmente envolvendo comércio energético, moldado pelos interesses russos (Chivvis 2017).

Para tanto, algumas características podem ser destacas neste tipo de GH instrumentalizada pela Rússia na anexação da Crimeia a seu território: a) economizar a força militar, já que usa de outros meios para aumentar sua legitimidade, como a mídia e a proximidade cultural a seu favor; b) a persistência, já que a razão do uso da GH é a mutação do conflito e c) é centrado na população, para maior aderência a legitimidade dos atos de política externa à invasão (Chivvis 2017).

É preciso observar, ainda, que a utilização do modelo de GH fornece ao Estado ampla gama de estratégias a serem implementadas simultaneamente durante a condução do conflito. (Hoffman 2009), ao analisar a modalidade, alerta para o perigo em distinguir as forças, uma vez que os métodos convencionais estão sendo 
implementados ao mesmo tempo, durante a GH. Essa diversidade tática torna a GH uma modalidade extremamente complexa, uma vez que o conflito passa a se desenrolar em diferentes níveis e ao mesmo tempo.

(Trenin 2018) argumenta que GH envolve um conflito global entre Rússia e EUA com diversos tipos de atores, estatais e não estatais, não se enquadrando no tipo de conflito convencional Estado-Estado, como na Guerra Fria. Desta forma, a interação internacional não é restrita por barreiras impostas pelos Estados que, além de envolver os governos nacionais, abrange corporações transnacionais, Organizações Internacionais e até indivíduos com interesses particulares.

Enquanto, tradicionalmente, a guerra irregular é vista como a estratégia de atores fracos frente a superioridade militar do seu inimigo, comumente utilizada por grupos insurgentes, guerrilhas e demais grupos intraestatais, essa modalidade sofre uma adaptação, se enxergada sob a luz da GH. Dentro do que (Hoffman 2009) entende como a guerra do futuro, em vez de ser uma característica de fraqueza, o oponente pode explorar estas estratégias dada a sua efetividade.

Essa leitura converge com a abordagem feita por (Dayspring 2015). Para esse autor, o uso da GH privilegia as escolhas do ator - seja ele um Estado ou um ente não estatal - que, mesmo possuindo forte grau de forças convencionais, escolhe atingir seus objetivos utilizando outros meios que não os puramente regulares. Tal possibilidade reduz o impacto clausewitziano do acaso, dotando o beligerante de maior autonomia sobre a implementação de seus recursos. Nesse sentido, também é reduzido o risco político de implementar estratégias convencionais, escalando um conflito que poderia ter menor escopo. GH, portanto, parece manobra eficaz, econômica e sagaz (Dayspring 2015).

Seguramente, o modelo russo merece atenção especial. Enquanto o termo Gibridnaya Voyna é tradução direta do termo Guerra Híbrida, o conceito que o fundamenta se assemelha mais à teoria da guerra da subversão do que à compreensão ocidental da GH (Fridman 2017). De acordo com os russos, a Gibridnaya Voyna consiste de tentativas de corroer a coesão sociocultural da população adversária, levando à substituição de um regime hostil por uma revolução colorida, com mínima (ou nenhuma) intervenção militar, se possível (Fridman 2017; Korybko 2015).

Sobre a relação entre Rússia - Ucrânia - UE, a dependência ocidental com relação ao gás natural da Rússia e a posição da Ucrânia em importar tecnologia nuclear dos Estados Unidos fez com que a Rússia tomasse medidas mais assertivas. Anteriormente a 2014, nem Rússia nem UE cogitavam a anexação da Crimeia. Segundo (Verner, Grigas e Petit 2019) em uma situação hipotética, a Rússia 
conseguiria permanecer longos períodos sem a troca comercial com os europeus, enquanto na mesma situação, a UE não passaria 30 dias sem a importação do gás russo.

Diante dos argumentos propostos, podemos sintetizar que o modelo de (Hermann 1990), especificamente nos dois estágios utilizados para explicar a tomada de decisão pelos formuladores de política externa, traz à tona como foi condicionada a ligação de causa e efeito frente o problema enfrentado pela Rússia e como esta agiu de forma a mudar sua PE. (Fernandes 2016) sustenta que o uso de GH é um mecanismo para que a Rússia alcance seus objetivos.

No quadro abaixo pode-se perceber as medidas de PE adotadas pela Rússia, associadas ao Modelo de (Hermann 1990) e o que se entende por GH conforme (Fernandes 2016, Chivvis 2017 e Trenin 2018).

Quadro 1: Aplicação Modelo Hermann (1990) e Guerra Híbrida

\begin{tabular}{|c|c|c|c|}
\hline $\begin{array}{c}\text { Governos } \\
\text { da Ucrânia }\end{array}$ & $\begin{array}{c}\text { Estágio } \\
\text { "postulação de uma conexão } \\
\text { entre o problema e a política" } \\
\text { (Hermann, 1990) }\end{array}$ & $\begin{array}{c}\text { Estágio } \\
\text { "implementação } \\
\text { de nova política" } \\
\text { (Hermann, 1990) }\end{array}$ & $\begin{array}{c}\text { CNV, NCNV } \\
\text { e HBD } \\
\text { (Fernandes, 2016) }\end{array}$ \\
\hline $\begin{array}{c}\text { Víktor } \\
\text { Yanukovytch }\end{array}$ & $\begin{array}{c}\text { Não ratificação de acordos com } \\
\text { UE: conflito civil pró-russos e } \\
\text { pró-ocidentais }\end{array}$ & $\begin{array}{c}\text { Militarização russa em } \\
\text { fronteira com a Ucrânia }\end{array}$ & CNV \\
\hline $\begin{array}{c}\text { Oleksandr } \\
\text { Turtchynov }\end{array}$ & $\begin{array}{c}\text { Tentativa de ratificação de } \\
\text { acordos com UE: "Golpe de } \\
\text { Estado" na Ucrânia }\end{array}$ & $\begin{array}{c}\text { Invasão à Crimeia pela } \\
\text { Federação Russa }\end{array}$ & HBD \\
\hline $\begin{array}{c}\text { Petro } \\
\text { Poroshenko }\end{array}$ & $\begin{array}{c}\text { Retorno das negociações } \\
\text { com UE }\end{array}$ & $\begin{array}{c}\text { Assinatura do tratado de } \\
\text { anexação da Crimeia à Rússia } \\
\text { por Putin e líderes da Crimeia }\end{array}$ & HBD \\
\hline
\end{tabular}

Legenda: UE (União Europeia); CNV: Guerra Convencional; NCNV: Guerra Não Convencional; HBD: Guerra Híbrida. Elaboração própria, com base em (Hermann 1990, Fernandes 2016, Chivvis 2017 e Trenin 2018).

Observando o quadro 1, acima, para cada governo ucraniano Putin agiu de maneira específica, ora por meios convencionais, ora não convencionais. No governo de Yanukovytch, devido a pressões externas russas de parceria internacional, o então presidente acabou não assinando os acordos com a UE, o que consequentemente acarretou uma onda de oposição pró-ocidental e militarização da fronteira russa-ucraniana como forma de pressão externa.

Contudo, nos dois governos subsequentes, Turtchynov e Poroshenko, verifica-se uma interpretação por parte de Putin de "golpe de Estado" e influência Ocidental nas decisões domésticas ucranianas, acarretando tomada de decisão mais assertiva e unidirecional, que pode ser entendida como $\mathrm{GH}$, pois a FR 
utilizou meios convencionais (medidas militares e uso de armamento bélico), e também meios não militares (utilizou a aproximação cultural que possui com a maioria da população da Crimeia para legitimar seus atos, com apoio da população).

Em contrapartida, a visão ocidental do entendimento de GH, (Tsygankov 2015) permite outra percepção sobre seu significado e seu uso pelos Estados Unidos para justificar conflitos internacionais. A utilização do termo, segundo o autor citado, é feita como ferramenta para manter domínio na política internacional. Além disso, o termo é instrumentalizado pelo ocidente com fins políticos, envolvendo informações enganosas, distorções de notícias, bem como o uso de ideologias para obtenção de vantagens, na obtenção de mudança de regimes internacionais indesejáveis em diversos países, bem como na combinação de métodos convencionais e não convencionais de guerra, negligenciando assim vidas humanas (Tsygankov 2015 256-257).

Na mesma linha de raciocínio, (Graham 2015) e (Dayspring 2015) levantam outro debate sobre GH. Este fenômeno proporciona, durante períodos de paz, a realização de objetivos estratégicos do país condutor, que acabam violando a soberania de outros. Estes objetivos, principalmente militares e coercitivos, podem apontar para resultados bem-sucedidos quando empregados de forma objetiva e por tempo determinado. Esse método pode reduzir a resposta internacional perante o curto tempo de duração do ato coercitivo.

(Zevelev 2001; 2008) vislumbra postura mais assertiva de Putin como governante integracionalista. Segundo o autor, Putin pode provar que a construção da nação russa e o integracionalismo com outras regiões são fenômenos compatíveis, já que possui apoio popular, mesmo considerando a grande variação étnica na Rússia. E esta variação étnica poderia justificar atitudes conflituosas em outros Estados soberanos próximos ao território russo, como os Estados pertencentes à Comunidade dos Estados Independentes (CEI), com o intuito de proteger a minoria russa da região invadida.

\section{Considerações Finais}

Conforme foi exposto neste artigo, a Rússia possui interesses explícitos quando se trata da sua relação com a Ucrânia. Consequentemente, todas as medidas de PE para a contenção da expansão do mercado Ocidental no país foram feitas/ 
tentadas para que a Rússia não perdesse suas importantes rotas comerciais de gás natural e petróleo, produtos energéticos significativos na manutenção do desempenho da economia russa.

A rápida mudança da PE feita por Putin, especificamente quando tropas russas invadiram à Crimeia, uma vez analisada pela aplicação do Modelo de Hermann, permite compreender a relação de causa e efeito levantada no problema do artigo. No que tange às duas características do modelo tratadas no artigo - (i) a "postulação de uma conexão entre o problema e a política" e a (ii) "implementação de nova política” - observou-se que: a ligação entre perda de mercado energético influenciado pela UE na Ucrânia com o novo direcionamento de governo para o lado pró-ocidental de Oleksandr Turtchynov foi motivo suficiente para que Putin mudasse seu posicionamento de neutro para ofensivo e usasse táticas de guerra que (Fernandes 2016), (Chivvis 2017) e (Trenin 2018) classificaram como Guerra Híbrida. Desta forma, Putin usou a seu favor elementos de guerra convencionais e não convencionais para atingir seus objetivos de PE, ou seja, utilizou recursos de HardPower e de SoftPower.

Invadir a Crimeia foi estrategicamente válido quando se analisa as medidas de PE aplicadas por Putin. A FR detinha a seu favor, além de forte armamento bélico e militar utilizado (métodos convencionais de guerra), o apoio da população da Crimeia, em torno de $90 \%$, legitimidade e influência da mídia local para persuasão psicológica, com uso de SoftPower neste ponto, por motivo da aproximação cultural entre ucranianos na Crimeia e russos (métodos não convencionais) (Segrillo, 2012; Mielniczuk, 2014; Fernandes, 2016).

O Modelo de Hermann (1990) e a base conceitual e operacional sobre Guerra Híbrida argumentado por Fernandes (2016), Chivvis (2017) e Trenin (2018) apresentaram a ligação de causa e efeito entre russos, ucranianos e Ocidente. As medidas de PE adotadas por Putin na Crimeia se mostram coerentes ao vislumbrar a tomada de decisão do governo na defesa de seus interesses.

\section{Referências}

Bandeira, Luiz Alberto Moniz. 2019. The Ukrainian Shift Away from Russia and Putin's Reaction. In: The World Disorder. Springer, Cham. p. 197-210. Disponível em: < https://link.springer.com/chapter/10.1007/978-3-030-03204-3_17 > . Acesso em: 16 Set. 2019. 
Barata, Pedro. 2014. A Ucrânia, a UE e a Rússia: Softpower versus Realpolitik. JANUS. NET e-journal of International Relations, Universidade Autónoma de Lisboa, Vol. 5, $\mathrm{N}^{\mathrm{o}}$ 1, p. 33-50, Maio-Outubro. Disponível em: < http://observare.ual.pt/janus.net/ images/stories/PDF/vol5_n1/pt/pt_vol5_n1_art3.pdf > . Acesso em: 31 de outubro de 2017. Chivvis, Christopher S. 2017. Understanding Russian “Hybrid Warfare”: And What Can Be Done About It: Addendum. National Security Research Division, RAND Corporation. Disponível em: < https://www.rand.org/content/dam/rand/pubs/testimonies/CT400/ CT468/RAND_CT468.pdf > . Acesso em: 02 de setembro de 2018.

Csaba, László. 1996. Transição e/ou modernização do Leste Europeu. Estud. Av., São Paulo, v. 10, n. 28, Dec. Available from < http://www.scielo.br/scielo.php?script = sci_ arttext\&pid $=$ S0103-40141996000300003\&lng $=$ en\&nrm $=$ iso $>$. Access on 25, Aug. 2018. < http://dx.doi.org/10.1590/S0103-40141996000300003 > .

Dayspring, Stephen M., 2015. Toward a theory of hybrid warfare: the Russian conduct of war during peace. Tese de Doutorado. Monterey, California: Naval Postgraduate School.

Dias, Vanda Amaro. 2015. As dimensões interna e internacional da crise na Ucrânia. Relações Internacionais, Lisboa, n. 45, p. 45-55, mar. Disponível em: < http://www. scielo.mec.pt/scielo.php?script = sci_arttext\&pid $=$ S1645-91992015000100003\&lng $=$ pt\&nrm $=$ iso $>$. Acesso em: 20 de novembro de 2017 .

Fernandes, H., 2016. The New Wars: The Challenge of Hybrid Warfare. Revista de Ciências Militares, novembro IV (2), pp. 41-67. Disponível em: < https://www.ium.pt/cisdi/ revista/Artigos/Artigo_133.pdf > . Acesso em: 25 de agosto de 2018.

Ferreira, Carlos Serrano. 2014. A presidência instável de Petro Poroshenko. Rev. Espaço Acadêmico, v. 14, n. 160. Disponível em: < http://periodicos.uem.br/ojs/index.php/ EspacoAcademico/article/view/24096 > . Acesso em: 16 Abr. 2019.

Freire, Maria Raquel. 2015. Política externa russa: as dimensões material e ideacional nas palavras e nas ações. E-cadernos ces [Online], Centro de Estudos Sociais da Universidade de Coimbra, $\mathrm{n}^{\circ}$ 19, p. 1-47. Disponível em: < http://eces.revues.org/ 1554\#tocfrom1n2 > . Acesso em: 20 de Outubro de 2017.

Fridman, Ofer, 2017. Hybrid Warfare or Gybridnaya Voyna?: Similar, But Different. The RUSI Journal, 162:1, 42-49 Disponível em: < http://www.tandfonline.com/doi/abs/ 10.1080/03071847.2016.1253370?journalCode $=$ rusi20 > . Acesso em: 19 de abril de 2019. Graham, Thomas. 2015. “Fragmentation of Russia.” In Russia after the Fall, edited by Andrew C. Kuchins, 39-61. Washington, DC: Carnegie Endowment for International Peace. Haran, Olexiy, Burkovsky, Petro. 2014. The Poroshenko Phenomenon: Elections and Challenges ahead. PONARS. Eurasia Policy Memo No. 336. August. Disponível em: < http://www.ponarseurasia.org/memo/poroshenko-phenomenon-elections-andchallenges-ahead > . Acesso em: 16 Abr. 2019. 
Hermann, Charles F. 1990. Changing course: when governments choose to redirect foreign policy. International Studies Quarterly, v. 34, n. 1, p. 3-21. Disponível em: < https://www.jstor.org/stable/2600403?seq=1\#metadata_info_tab_contents > . Acesso em: 04 de setembro de 2018.

Hoffman, Frank G. 2009. Hybrid threats: Reconceptualizing the evolving character of modern conflict. Washington, DC: Institute for National Strategic Studies, National Defense University.

Korybko, Andrew. 2015. Hybrid Wars: The Indirect Adaptive Approach to Regime Change. Peoples' Friendship University of Russia. Moscow.

Kossovsky, N. Carley, K. M. 2019. The collapse of the second Yatsenyuk government: roll call vote and dynamic network analysis. Computational and Mathematical Organization Theory Disponível em: < https://link.springer.com/article/10.1007/ s10588-019-09294-5 > . Acesso em: 16 Abr. 2019.

Lewis, Barbara. 2014. European leaders seek ways to curb dependence on russian gas. Reuters, Bruxelas, 19 mar. Disponível em: < http://www.reuters.com/article/ 2014/03/19/ukraine-crisis-energy-idUSL6N0LN26720140319 > . Acesso em: 20 de novembro 2017.

Levada Center. 2019. Russian Public Opinion - 2018. Acesso em: 22 de outubro de 2019. Disponível em: < https://www.levada.ru/cp/wp-content/uploads/2019/07/2018Eng.pdf $>$.

Lijphart, Arend. 2003. Modelos de Democracia: Desempenho e padrões de governo em 36 países. Rio de Janeiro: Civilização Brasileira.

Mielniczuk, Fabiano. 2014. A crise ucraniana e suas implicações para as Relações Internacionais. Revista Conjuntura Austral. Rio Grande do Sul. V. 05, n. 23, abril/maio. Disponível em: < https://www.academia.edu/14925140/A_Crise_Ucraniana_e_suas_ Implica \% C3 \% A7 \% C3 \% B5es_para_as_Rela \% C3 \% A7 \% C3 \% B5es_Internacionais > . Acesso em: 20 de novembro 2017.

Mulder, Patrick et al. 2019. Understanding Russia’s annexation of Crimea: A perspective through Strategic Culture Analysis. [Dissertação de Mestrado] International Relations, Universiteit Leiden. Disponível em: < https://openaccess.leidenuniv.nl/ handle/1887/75124 > . Acesso em: 16 Set. 2019.

Obydenkova, Anastassia. V. 2011. A Triangle of Russian Federalism: Democratization, (De-) Centralization, and Local Politics. Publius: The Journal of Federalism, 41(4), 734-741. Disponível em: < https://academic.oup.com/publius/articleabstract/41/4/734/1862280 > . Acesso em: 16 Set. 2019.

Organização das Nações Unidas ONU. 2014. World Report 2014 - Events of 2013. Relatório. Estados Unidos. Disponível em: < http://www.hrw.org/sites/default/files/ wr2014_web_0.pdf > . Acesso em: 31 de outubro de 2017. 
Segrillo, Angelo. 2012. A questão da democracia na Rússia pós-soviética. In: Alves, André Gustavo de Miranda Pineli (Org.). O renascimento de uma potência? A Rússia no século XXI. Brasília. p. 97-128. Disponível em: < http://repositorio.ipea.gov.br/ handle/11058/3042 > . Acesso em: 31 de outubro de 2017.

Silva, Hugo Miguel Garcia. 2018. A União Europeia e o conflito ucraniano: atuais medidas de política de segurança e de defesa e perspectivas futuras. [Dissertação] Escola de Ciências Sociais. Departamento de Economia. Universidade de Évora. Évora. Disponível em: < http://dspace.uevora.pt/rdpc/handle/10174/23662 > Acesso em: 16 abr. 2019.

The European Center of Excellence for Countering Hybrid Threats. 2019. Hybrid Threats: Countering Hybrid Threats. Disponível em: < https://www.hybridcoe.fi/hybridthreats/ > . Acesso em: 16 Set. 2019.

Trenin, Dmitri. 2018. Avoiding US-Russia Military Escalations during the Hybrid War. Carnegie Endowment for International Peace. January. Disponível em: < https://carnegieendowment.org/files/Trenin_Hybrid_War_web.pdf > . Acesso em: 02 de setembro de 2018 .

Tsygankov, P.A. 2015. "Hybrid war": political discourse and the international practice. Moscow State University Bulletin. Series 18. Sociology and Political Science. (4):253-258. (In Russ.). Disponível em: < https://vestnik.socio.msu.ru/jour/article/ view $/ 137$ ? locale $=$ en_US $>$. Acesso em: 16 Set. 2019.

Tronenko, Rostyslav. 2016. Ucrânia: Luta pelo direito de escolher seu destino, pela sua soberania e integridade territorial. Centro Universitário de Brasília (UniCEUB). Rev. Universitas Relações Internacionais, Brasília, v. 14, n. 1, p. 103-115, jan./jun. Disponível em: < https://www.publicacoesacademicas.uniceub.br/relacoesinternacionais/ article/view/4116 > . Acesso em: 24 de agosto de 2018.

Verner, Duane. Grigas, Agnia. Petit, Frederic. 2019. Assessing Energy Dependency in the Age of Hybrid Threats. Energy and Global Security Directorate Argonne National Laboratory. The European Centre of Excellence for Countering Hybrid Threats. Disponível em: < https://www.hybridcoe.fi/wp-content/uploads/2019/02/Assessing Energy_Dependency_in_the_Age_of_Hybrid_Threats-HybridCoE.pdf $>$. Acesso em: 16 Set. 2019.

World Bank. 2017. World Integrated Trade Solutions (WITS). Accessed in 25 oct. Available in: < https://wits.worldbank.org/CountryProfile/en/Country/UKR/Year/2015/ TradeFlow/Import/Partner/all/Product/27-27_Fuels $>$.

World Bank. 2017. World Integrated Trade Solutions (WITS). Accessed in 25 oct. 2. Available in: < https://wits.worldbank.org/CountryProfile/en/Country/UKR/ Year/2015/TradeFlow/Import/Partner/RUS/Product/all-groups\# > . 
World Trade Organizations (WTO). 2018. International Trade and Market Access Data. Disponível em: < https://www.wto.org/english/res_e/statis_e/statis_bis_e.htm? solution $=$ WTO\&path $=/$ Dashboards $/$ MAPS\&file $=$ Map. wcdf\&bookmarkState $=\{\% 22 \mathrm{impl} \% 22: \% 22$ client $\% 22, \% 22$ params $\% 22:\{\% 22$ langParam $\% 22: \% 22$ en $\% 22\}\}>$. Acesso em: 20 de agosto 2018 .

Zevelev, Igor. 2001. Russia and Its New Diasporas. Washington, DC: United States Institute of Peace Press.

Zevelev, Igor. 2008. Russia's Policy toward Compatriots in the Former Soviet Union,” Russia in Global Affairs 6, no. 1 (January - March). Disponível em: < http://eng. globalaffairs.ru/number/n_10351 > . Acesso em: 16 Set. 2019. 